\title{
IMPLEMENTATION OF SCHOOL-BASED MANAGEMENT PROGRAM IN PUBLIC ELEMENTARY SCHOOL
}

\author{
Djum Djum Noor Benty \\ Department of Educational Management \\ State University of Malang, Indonesia \\ dj.noor.benty@gmail.com
}

\author{
Achmad Supriyanto \\ Department of Educational Management \\ State University of Malang, Indonesia \\ a.supriyanto.fip@um.ac.id
}

\begin{abstract}
This study aims to describe the implementation of school-based management (SBM) program in public elementary school in Blitar City, East Java Province. This study uses a quantitative approach and is included in the type of descriptive research. Source of data in this study is the principal of public elementary schools in the city of Blitar which amounted to 34 . The main tool to collect data in this study is a questionnaire that was prepared based on the concept of measurement Likert Scale. The data analysis techniques using descriptive statistical analysis techniques. The results of data analysis show that the implementation of SBM program in public elementary school in Blitar city as a whole has been successfully implemented. But there are some components of SBM that still need to be improved again.
\end{abstract}

Keywords: Implementation, School-based management

\section{INTRODUCTION}

The process of building education is essentially a whole human being as a quality subject. Building a complete humanity in essence develops all its potential as a human being through the balance of heart, thought, exercise, sports done as the development of civilization of the nation. On that basis, an important step forward is to determine the development and direction of education in the homeland in order to educate the nation's life as mandated by the 1945 Constitution which explicitly states that every citizen is entitled to education.

The determination to continue to give great attention to the development of education considering that education has a strategic role in the life of the nation and provide a significant participation on economic growth and social transformation. This in turn will affect the general welfare of society and the world order more broadly. Indirect education will also create a society that is independent, democratic, prosperous and free from poverty. One continuous effort to realize quality education is to make changes in schools by implementing school-based management, which emphasizes the development of school planning, improving school quality, implementing new curricula, and applying information technology applications in education [2].

Within the framework of regional autonomy, the responsibility to meet the demands of quality education is fully available to the district/city government. The fact that the various limitations of the government, especially in terms of funding, the government needs to develop a comprehensive strategy both short, medium, and long term to realize a quality education. Implementation of autonomy in the field of education in terms of institutional education requires the management of education need to consider and consider some potential aspects so that the school institutions can realize and display its role as a container for the development of quality human resources.

School Based Management is a new paradigm of education that provides broad autonomy at the school level within the framework of national education policy. This autonomy is given to schools to freely manage resources and resources by allocating according to priority needs and more responsive to local needs. In other words that the SBM requires schools to independently explore, allocate, prioritize, control and account for the empowerment of the sources of both the community and the government. Judging from the policy in Indonesia, the sustainability of SBM programs in Indonesia needs to be maintained and improved continuously. As stated in Law Number 20 Year 2003 on National Education System In Article 51 Paragraph (1) it is stated that "the management of early childhood education units, primary and secondary education are implemented based on minimum service standards based on the principles of school/madrasah based management".

However, the reality in the field shows that the momentum of regional autonomy causes the orientation of inter-regional education implementation seems increasingly lost direction because of the way of view that is independently developed by the education apparatus in the district / city in determining the policy of education implementation. On the other hand, there is still a lack of awareness of commitment to improve the quality and consistency to design and realize all programs that lead to the achievement of the quality of education graduates. This is the result of [8] research, that the obstacles faced in the implementation of SBM program are related to the mindset of some stakeholders who do not really respond to changes in government policy in the field of education. This indicates that the implementation of the SBM program is still experiencing problems. Meanwhile, the research results of [5] concluded that the implementation of SBM in Indonesia faces various problems mainly related to the 7 components of SBM.

The results of monitoring and evaluation of SBM implementation in primary schools (SD) conducted by Directorate of Primary and Secondary Education, Directorate General of Primary and Secondary Education, Ministry of National Education in 2012, 2013, 2014, and 2015, indicate that SD in Indonesia varies in the implementation of SBM both quantity and quality, there are various obstacles to the 
implementation of SBM, and there have been efforts in the field to overcome the obstacles of SBM implementation but have not been able to solve the overall constraints.

When analyzed in the field related to the implementation of SBM program in Blitar City has not been implemented optimally, this is indicated by: (1) there are some schools have not implemented transparent, participatory, accountable and independent school management to build education democracy; (2) Lack of participation and responsibility of the community and parents in assisting/supporting school development, activity planning and budgeting, and control of schools; And (3) the capacity of human resources, both principals and teachers are still very limited especially in the implementation of SBM programs, only a few have implemented the SBM program. The result of the research by Timan (2015) on Community Participation in Improving the Quality of School in Blitar City shows: (1) the school is not optimal in empowering community participation in quality improvement, and (2) the academic achievement of the graduates in Blitar Elementary School is not maximal yet Efforts to improve. One element in the SBM program is community participation, therefore the results of these studies need to be followed up in similar activities, especially related to the implementation of the SBM program.

\section{METHODS}

This research was conducted simultaneously with the implementation of community service with the theme of improving the quality of education through the implementation of school-based management program in Blitar City. This study uses descriptive research design that seeks to explore data, describe and analyze it so that it can answer the main problem of research. The population in this study covers all principals of State Elementary School in Blitar City, amounting to 34 people. Thus the entire population is used as a source of data in this study. Variable in this research type of single variable that is school based management program.

As for the sub-variables in this study are all the components in the school-based management program that includes: curriculum and learning management, students, educators and education personnel, finance schools, facilities and infrastructure, public relations, and culture and environment school. The main tool for collecting data in this study is a questionnaire compiled based on the Likert Scale measurement concept. This instrument is developed by researchers using a scale of 1 to 5. The data analysis techniques using descriptive statistical analysis techniques.

\section{RESULTS AND DISCUSSION}

School Based Management (SBM) Program established by the Government of Indonesia in this case the Ministry of Education and Culture since 2012 covers various components, namely: curriculum and learning management, students, educators and education personnel, school financing, facilities and infrastructure, public relations, and culture school environment.

Based on the results of the analysis, the MBS program implementation of the whole components, as presented in Table 1.

Table 1

Implementation of SBM Program in Blitar City

\begin{tabular}{ccccc}
\hline Category & Frequency & Percent & Valid Percent & Cumulative Percent \\
\hline Good & 1 & 2,9 & 2,9 & 2,9 \\
Averege & 26 & 76,5 & 76,5 & 79,4 \\
Poor & 7 & 20,6 & 20,6 & 100,0 \\
\hline Total & 34 & 100,0 & 100,0 & \\
\hline
\end{tabular}

Based on Table 1, it is known that from 34 respondents only 1 or $2.9 \%$ of schools have implemented "good" SBM programs, 26 or $76.5 \%$ of schools are in the "average" category implementing SBM programs, while 7 or $20.6 \%$ of schools are categorized as "poor". Implementation of SBM components in detail can be illustrated as follows.

\section{a. Curriculum and Learning Management}

The description of the results of the analysis on the sub-variables of curriculum and learning management, in detail can be seen in Table 2 .

Based on Table 2, it can be illustrated that the $38.2 \%$ or 38.2 elementary schools in the implementation of curriculum management and learning fall into the "poor" category, and $35.3 \%$ or 12 elementary schools fall into the "average" category. However, there are elementary schools that have implemented the "good" as much as $20.6 \%$, and $5.9 \%$ in the "excellent" category. Thus it can be concluded that elementary school in Blitar City in implementing curriculum and learning management in "poor" category. This means that in this component, most elementary schools in Blitar City fail to implement curriculum and learning management.

\section{b. Management of Learners}

The results of this sub-variable analysis indicate that there are 2 or $5.9 \%$ of elementary schools in the "excellent" category, 6 or $17.6 \%$ of elementary schools in the "good" category, while 14 or $41.2 \%$ elementary schools are in the "average" category, and the rest are 12 elementary schools or $35.5 \%$ in the "poor" category. The following is more clearly presented in Table 3.

Based on Table 3, it can be concluded that elementary schools in Blitar City have implemented the management of learners in the "average" category. 
Table 2

\begin{tabular}{ccccc}
\multicolumn{6}{c}{ Implementation of Curriculum and Learning Management } \\
\hline Category & Frequency & Percent & Valid Percent & Cumulative Percent \\
\hline Excellent & 2 & 5,9 & 5,9 & 5,9 \\
Good & 7 & 20,6 & 20,6 & 26,5 \\
Average & 12 & 35,3 & 35,3 & 61,8 \\
Poor & 13 & 38,2 & 38,2 & 100,0 \\
\hline Total & 34 & 100,0 & 100,0 \\
\multicolumn{5}{c}{ Table 3 } \\
\hline \multicolumn{5}{c}{ Implementation Management of Leaners } \\
\hline Category & Frequency & Percent & Valid Percent & Cumulative Percent \\
\hline Excellent & 2 & 5,9 & 5,9 & 5,9 \\
Good & 6 & 17,6 & 17,6 & 23,5 \\
Average & 14 & 41,2 & 41,2 & 64,7 \\
Poor & 12 & 35,3 & 35,3 & 100,0 \\
\hline Total & 34 & 100,0 & 100,0 & \\
\hline
\end{tabular}

\section{c. Management of Educators and Education Personnel}

The description of the results of the analysis in this sub-variable, in detail can be seen in Table 4.

Based on Table 4, it can be seen that there are 4 or $11.8 \%$ of primary schools in the category of "excellent", as many as 9 or $26.5 \%$ are in the category of "good", most of which ranged 13 or $38.2 \%$ "Average", $20.6 \%$ or 7 elementary schools belong to the "poor" category, and only one elementary school is in the "Unsatisfactory" category

Thus it can be concluded that in this component, most primary schools in Blitar City can be said successful in the implementation of management educators and educational personnel.

\section{d. School Finance Management}

The description of the results of the analysis of this sub-variable is 7 or $20.6 \%$ in the "good" category, 15 or $44.1 \%$ in the "average" category, 11 or $32.4 \%$ are in the "poor" category, and only 1 is in the category "unsatisfactory". In more detail, the following is presented in Table 5.

Based on Table 5, it can be concluded that the implementation of financing management by elementary school in Blitar City included in success category.

Table 4

\begin{tabular}{ccccc}
\multicolumn{6}{c}{ Implementation of Management Educators and Education Personnel } \\
\hline Category & Frequency & Percent & Valid Percent & Cumulative Percent \\
\hline Excellent & 4 & 11,8 & 11,8 & 11,8 \\
Good & 9 & 26,5 & 26,5 & 38,2 \\
Average & 13 & 38,2 & 38,2 & 76,5 \\
Poor & 7 & 20,6 & 20,6 & 97,1 \\
Unsatisfactory & 1 & 2,9 & 2,9 & 100,0 \\
\hline Total & 34 & 100,0 & 100,0 & \\
\hline
\end{tabular}

Table 5

Implementation of School Finance Management

\begin{tabular}{ccccc}
\hline Category & Frequency & Percent & Valid Percent & Cumulative Percent \\
\hline Good & 7 & 20,6 & 20,6 & 20,6 \\
Average & 15 & 44,1 & 44,1 & 64,7 \\
Poor & 11 & 32,4 & 32,4 & 97,1 \\
Unsatisfactory & 1 & 2,9 & 2,9 & 100,0 \\
\hline Total & 34 & 100,0 & 100,0 & \\
\hline
\end{tabular}

\section{e. Management of Facilities and Infrastructure}

In the components of facilities and infrastructure, the analysis shows that there are 10 schools or approximately $29.4 \%$ are in "good" category, as many as 17 or $50 \%$ of schools implement the management of facilities and infrastructure with "average", 5 schools or $14.7 \%$ in "poor" category, and 2 or $5.9 \%$ of schools are in "unsatisfactory" category. In detail as presented in Table 6. Thus it can be concluded that most elementary schools in Blitar City have been successful in implementing school-based management facilities and infrastructure.

\section{f. Public Relations Management}

The component of public relations management is more directed to the activities of community participation towards school programs. From the results of the analysis, obtained data as in Table 7.

Based on Table 7, it is known that 6 or $17.6 \%$ of schools are categorized as "good", 15 or $44.1 \%$ of schools are in the "average" category, 9 or $26.5 \%$ of schools in "poor" category, and 4 schools or $11.8 \%$ in the "unsatisfactory" category. Thus it can be concluded that the components of public relations management have been implemented successfully. 
g. Cultural Management and School Environment

This component focuses more on school efforts in managing the prevailing culture in schools and environmental arrangements that support the learning process of children in schools, so as to create a cultural and school environment that is conducive to the creation of an effective learning process. From the analysis results obtained data as presented in Table 8 .
Based on the data presented in Table 8 , it is known that there are 1 schools in the "excellent" category, 2 schools in the "good" category, 17 schools or $50 \%$ are in the "average" category, 9 schools or $26.5 \%$ Poor ", and 5 schools or $14.7 \%$ belong to the category" unsatisfactory ". Thus it can be concluded that the implementation of components of cultural management and school environment can be said to have not succeeded.

Table 6

Implementation of Infrastructure Management

\begin{tabular}{ccccc}
\hline \multicolumn{7}{c}{ Implementation of Infrastructure Management } \\
\hline Category & Frequency & Percent & Valid Percent & Cumulative Percent \\
\hline Good & 10 & 29,4 & 29,4 & 29,4 \\
Average & 17 & 50,0 & 50,0 & 79,4 \\
Poor & 5 & 14,7 & 14,7 & 94,1 \\
Unsatisfactory & 2 & 5,9 & 5,9 & 100,0 \\
\hline Total & 34 & 100,0 & 100,0 &
\end{tabular}

Table 7

Implementation of Public Relations Management

\begin{tabular}{ccccc}
\hline Category & Frequency & Percent & Valid Percent & Cumulative Percent \\
\hline Good & 6 & 17,6 & 17,6 & 17,6 \\
Average & 15 & 44,1 & 44,1 & 61,8 \\
Poor & 9 & 26,5 & 26,5 & 88,2 \\
Unsatisfactory & 4 & 11,8 & 11,8 & 100,0 \\
\hline Total & 34 & 100,0 & 100,0 & \\
\hline
\end{tabular}

Table 8

Implementation of Cultural Management and School Environment

\begin{tabular}{ccccc}
\hline Category & Frequency & Percent & Valid Percent & Cumulative Percent \\
\hline Excellent & 1 & 2,9 & 2,9 & 2,9 \\
Good & 2 & 5,9 & 5,9 & 8,8 \\
Average & 17 & 50,0 & 50,0 & 58,8 \\
Poor & 9 & 26,5 & 26,5 & 85,3 \\
Unsatisfactory & 5 & 14,7 & 14,7 & 100,0 \\
\hline Total & 34 & 100,0 & 100,0 & \\
\hline
\end{tabular}

The results of the research as described previously indicate a problem arising in the implementation of SBM in Blitar City. These conditions can prove that the implementation of SBM program in Blitar City has not run optimally. It is certainly necessary to have an intensive improvement or coaching for the principals, especially in the city of Blitar in the implementation of the SBM program. This is as revealed by [7] that the result suggest the prograsm had substantial positive effects on third grade Spainsh test score, with the most benefits accruing to school receiving

The essence of SBM is a form of autonomy strengthening to schools, which can be interpreted as giving wider authority to schools to manage themselves according to the characteristics they possess by referring to prevailing policies and regulations. School autonomy in this context is interpreted as a granting of more autonomous authority in managing education. Thus SBM aims to improve school self-sufficiency through the granting of greater authority in managing school resources, and encouraging the participation of all interest groups associated with schools in decision-making to achieve school quality improvement objectives.

Schools as autonomous educational institutions are given wide authority and powers to be able to develop curriculum and learning programs according to the conditions and needs of learners. Schools are given freedom in learning innovation, freedom in designing intra and extracurricular activities, and other authorities in the field of curriculum.

Schools are also given the authority to explore and manage the source of funds from the community according to the needs of school development. The existence of the government's "free school" program and Bantuan Operasional Sekolah (BOS) are interpreted as diverse, some argue that schools simply can not get funds from the community because they are fully borne by the government. Researchers argue that the existence of these two programs, the school still allows to explore the sources of funding from the community in order to improve the quality of schools.

In the field of manpower, schools have the authority to nurture and develop professional education personnel in accordance with the needs and the ability of schools. Similarly, the authority in the field of student affairs, facilities and infrastructure, public relations, and culture and school environment. This is in line with [3] that SBM also means that management and decision making in curriculum, personnel, financial and budget planning are made at school level. 
Similarly, as disclosed by [6] that it is belive of school, school effectiveness and improve student achievement.

Implementation of SBM needs to be continuously optimized. [1] asserted that for the successful implementation of SBM, a pattern or paradigm should be developed to think about building potential management capabilities, as well as building school communities as a vehicle for learning together.

\section{CONCLUSION}

Implementation of the overall SBM program has been successfully implemented by most elementary schools in Blitar City. However, when viewed from the aspect of the SBM component, there are three SBM components that still need to be improved, such as: curriculum and learning management, students, and school culture and environment. Where in the three components is still low when compared with four other components of SBM.

\section{ACKNOWLEDGMENTS}

The researchers thank the Dean of the Faculty of Education, State University of Malang which has provided a research grant. Furthermore, thanks are also addressed to Mr. Mokhamad Sidik, S. Sos, M.Ap Head of Education Office of Blitar City, who has given permission and assistance in this research.

\section{REFERENCES}

[1] Ansar. 2012. Manajemen Berbasis Sekolah dalam Kerangka Penguatan Otonomi Sekolah. Proceding International Conference Educational Management, Administration and Leadership. p. 58-64.

[2] Caldwell, B. J. and Spinks, J. M. 1992. Leading the Self Managing School. London: The Falmer Press.

[3] David, J.L. 1996. The Who, What, and Why of SiteBased Management. Educational Leadership, Jan. p. 49.

[4] Kementerian Pendidikan dan Kebudayaan. 2013. Panduan Pembinaan MBS Tahun 2013. Jakarta: Direktorat Pembinaan Sekolah Dasar, Direktorat Jenderal Pendidikan Dasar dan Menengah.

[5] Mustiningsih. 2015. Masalah Implementasi Manajemen Berbasis Sekolah di Sekolah Dasar. Manajemen Pendidikan, 24, 6, 498-505.

[6] Odden, E., \& Wholstetter, P. 1995. Making SchoolBased Management Work. Educational Leadership, 52. p. 32-36.

[7] Santibanes, L., Lastra, R. A., \& O’Donoghue, J. L. 2014. School Based Management Effects: Resources or Governance Change? Evidance from Mexico. Economic of Education Review, 39, p. 97-109.

[8] Sentosa, I. P. P. 2012. Studi Evaluasi Pelaksanaan Program Manajemen Berbasis Sekolah (Studi Pada Tiga Sekolah Menengah Pertama yang Sebelumnya Menjadi Rintisan Program Manajemen Peningkatan Mutu Berbasis Sekolah di Kabupaten Jembrana). Jurnal Penelitian Pascasarjana Undiksa, 2, 2, 1-10.

[9] Timan, A. 2015. Manajemen Partisipasi Masyarakat dalam Meningkatkan Mutu Pendidikan di Sekolah Dasar. Dissertation. Malang: State University of Malang.

[10] Undang-undang Nomor 20 Tahun 2003 tentang Sistem Pendidikan Nasional. Bandung: Citra Umbara. 